\title{
Healthy ayeing as a visible public health activity and governmental responsibility. Health Promotion for Older People in the Czech Republic. Institutional and financial dimension
}

\author{
Agnieszka Sowa ${ }^{1}$, Anna Szetela $^{2}$
}

\begin{abstract}
${ }^{1}$ Institute of Labour and Social Studies, Warsaw, Poland; ${ }^{2}$ Institute of Public Health, Faculty of Health Sciences, Jagiellonian University Medical College, Cracow, Poland

Address for correspondence: Agnieszka Sowa, Institute of Labour and Social Studies, Bellottiego 3B St., 01-022, Warsaw, Poland, a.sowa@ipiss.com.pl
\end{abstract}

\section{Abstract}

The health status of the Czech population has been improving over the past decades. The life expectancy increased from 67.6 for men/75.5 for women in 1990 to 75.9 for men/82.1 for women in 2014, becoming one of the highest in the Central and Eastern European region. Still, the older population faces many health risks related to obesity, high alcohol consumption, physical inactivity and smoking. Over half of the population above the age of 65 suffers from long-lasting illnesses and over half of the population above the age of 75 reports limitation in activities.

Health promotion for older people in the Czech Republic is growing in importance. There have been nationwide health promotion programmes against the main civilisation diseases, which older people could benefit from. In recent years two strategic programmes: the National Strategy for Health Protection and Promotion and Disease Prevention and the National Action Plan for Positive Ageing for the period of 2013-2017 came into existence with healthy ageing being an important target for both of them.

Health promotion policy is strongly centralised, supervised on the one hand by the Ministry of Health and the National Institute of Public Health and on the other hand by the Ministry of Labour and Social Affairs. At the same time, the activity of local governments and - especially - non-governmental organisations is important in supporting visible health promotion programmes for older people at the local level.

Key words: public health, Health Promotion for Older People, healthy ageing, central government, Iocal governments, non-governmental organisations, Czech Republic

\section{Introduction}

The objective of the report is to assess health promotion policy and provide an overview of activities in the area of health promotion for older people in the context of the health care system and population changes in the Czech Republic. The report contains a short description of the main features of the health care system, followed by brief recognition of the demographic changes and a description of the main health problems of the older population. Furthermore, ageing policy is described and examples of health promotion activities for older people are given.

The assessment is based on the literature, policy and statistical databases overview in the health promotion field. The reports and articles cited have been taken from PubMED database; policy documents have been taken from the websites of the Czech Ministry of Health, Ministry of Labour and Social Affairs and the National Institute of Public Health. Statistical databases used include OECD Health data, Eurostat data based on EU-SILC survey and data of the Czech Statistical Office. 


\section{The health care system and public health policy in the Czech Republic}

The health care system in the Czech Republic is rooted in the 19th century in the Austro-Hungarian empire and traditionally, access to health services and funding were based on Bismarckian type insurance plans. This was abandoned in the communist era, firstly when health insurance funds were unified in 1948 and secondly when the insurance based system was replaced in 1952 with the Semaskho model, funded from the central budget [1]. After the Velvet Revolution in the Czechoslovakia, health care system reform was one of the main priorities in redesigning the welfare state [2]. New health care laws were passed and a social health insurance system was reintroduced already in 1991/1992 with a number of quasi-funded, self-governed health insurance funds acting as payers and purchasers of medical services [1]. Initially numerous health insurance funds were unable to meet strict market criteria and due to service overuse, resulting in the health care system deficit, some of them collapsed, others merged what resulted in limiting the number of health insurers in the following years [3]. By 2014 the number of health insurance funds had decreased to seven [1]. The health insurance premium is compulsory. For employees it is shared between the employee and the employer [4], while self-employed workers contribute a fixed percentage of their profits. For economically inactive persons, contributions are paid by the state [5].

The total health expenditure in the Czech Republic account for $7.5 \%$ of the GDP and have increased in relation to the GDP by one third over the past 15 years (Table I), though the level of expenditure is not high compared to other European countries (i.e. in Germany
$-11.1 \%$ of the GDP, Netherlands $-10.8 \%$ of the GDP, Poland $-6.3 \%$ of the GDP). The majority of expenditures $(83.5 \%)$ are covered by the general public budget and, although this share has slightly decreased over the past years, it remains very high. Expenditures related to public health and prevention are small, constituting about $0.2 \%$ of the GDP [5] and 3\% of the total health expenditure. Despite being at a very low level, these expenditures have doubled since 2000 .

Public health activities are supervised by the National Institute of Public Health (NIPH - SZÚ), established, strikingly early, 1921. During the second half of the 20th century, in communist Czechoslovakia, public health concentrated on disease control and prevention [6]. Since the 1960s the behavioural aspects of health, health education and information have become important elements of public health policy. In the 1990s in the Czech Republic public health was reshaped to be in line with the recommendations of the Ottawa charter (1986) with even more attention given to public health promotion and information. Health protection and right to health care is also guaranteed by the Charter of Human Rights and Freedoms which is a part of the Czech Constitution. Several international health promotion programmes were initiated, although not all of them were completed successfully, mainly due to poor citizen response, a lack of social networking and social capital in the society in the process of the political and economic transformation [6]. Nowadays the NIPH is the main public health institution, supervised by the Ministry of Health with the chief public health officer being the deputy of minister of health. NIPH responsibilities are set by the Public Health Act, ${ }^{1}$ adopted in 2000 (with further amendments). They include coordination and planning of public health activities, pre-

\begin{tabular}{|l|c|c|c|c|c|c|c|c|c|c|c|}
\hline & 2000 & 2005 & 2007 & 2010 & & 2012 & 2013 & 2014 & 2015 & $\begin{array}{c}\text { Change } \\
2000 \text { to } \\
2013\end{array}$ & $\begin{array}{c}\text { Change } \\
2007 \text { to } \\
2013\end{array}$ \\
\hline $\begin{array}{l}\text { Current health } \\
\text { expenditure per } \\
\text { capita. Constant } \\
\text { prices OECD } \\
\text { base year in } \\
\text { koruna }\end{array}$ & $16,170.80$ & $21,956.50$ & $23,149.60$ & $26,208.80$ & $26,835.80$ & $28,318.50$ & $29,462.80$ & $30,208.50$ & $86.8 \%$ & $30.5 \%$ \\
\hline $\begin{array}{l}\text { Current health } \\
\text { expenditure as } \\
\% \text { of GDP }\end{array}$ & 5.7 & 6.4 & 6.0 & 6.9 & & 7.1 & 7.8 & 7.7 & 7.5 & $31.6 \%$ & $25.0 \%$ \\
\hline $\begin{array}{l}\text { Share of general } \\
\text { government in } \\
\text { current health } \\
\text { expenditures }\end{array}$ & 89.8 & 86.8 & 84.7 & 83.3 & & 83.7 & 84.1 & 83.8 & 83.5 & $-7.0 \%$ & $-1.4 \%$ \\
\hline $\begin{array}{l}\text { Share of preven- } \\
\text { tion and public } \\
\text { health serv- } \\
\text { ices in current } \\
\text { expenditure on } \\
\text { health }\end{array}$ & 1.6 & 1.7 & 2.3 & 2.5 & & 2.1 & 2.7 & 3.2 & n.a. & $100.0 \%$ & $39.1 \%$ \\
\hline
\end{tabular}

Table I. Main health care system indicators.

Source: OCED Health data, http://stats.oecd.org/index.aspx?DataSetCode=HEALTH_STAT\#; accessed: 10.09.2016. 
vention of communicable diseases, research, monitoring of the population's health, collecting epidemiological data on the main communicable and non-communicable chronic diseases and supervising occupational safety and sanitation (drinking water, food and catering). Under the umbrella of its activities, the NIPH coordinates national health policy programmes oriented towards the improvement of adults' and older people's health. Its activities range from nationwide programmes to individual consultancies. The thematic range of activities is wide, also covering programmes oriented towards health improvement, information and promoting a healthy lifestyle for older people [1].

In the Public Health Act, health protection and promotion are defined as a sum of activities and measures aimed at the protection of healthy living and working conditions, prevention of the spread of infectious diseases and the high prevalence of civilisation diseases and decreasing occupational health risks and occupational diseases. Besides the act on public health, which is the most important legal regulation in this field in the Czech Republic, the legal framework for public health is created by the governmental resolution on Long-term programmes for improvement of the population's health in the Czech Republic - Health for All in the $21^{\text {st }}$ Century, ${ }^{2}$ regulations on environmental health ${ }^{3}$ and regulations on health in the workplace ${ }^{4}$ (occupational health and work safety).

\section{The demographic situation and the health status of older people}

The health status of the Czech population has been improving over the past decades (Box 1). The life expectancy increased from 67.6 for men/75.5 for women in 1990 to 75.9 for men/82.1 for women in 2014, becoming one of the highest in the Central and Eastern European region. In the population aged 65 years, life expectancy improved from 11.7 for men/15.4 for women in 1990 to 16.2 for men/19.9 for women in 2014 [1].

The main reason for the remarkable health improvement was the decrease of cardiovascular system disease mortality in the total population [6]. Health improvement, although significant, does not correlate to living in older age in good health and a high quality of life, as almost half of time lived above the age of 65 involves the occurrence of morbidity (or multimorbidity) and, in some cases, also disability and limitations in everyday activities (Box 2).

\section{Institutional settings for health promotion and prevention}

Prevention and health promotion is an important policy field with a number of institutions involved in health promotion in the Czech Republic. The central government level institutions responsible for priority set-

The Czech Republic has entered the ageing phase with the share of its population aged 65-79 slightly above the EU-28 average (13.9\% compared to $13.4 \%$ ) in 2015 . The proportion of the oldest old (80+) in the population accounts for $4.0 \%$ in 2015 and is still below the EU-28 average of $5.4 \%$. Given the low birth rates and increase in longevity, the share of older people $(65+)$ in the Czech population is foreseen to increase to $28.6 \%$ by 2060 . At the same time, the proportion of the oldest old is foreseen to almost triple $(11.4 \%)$ in the next 45 years. The old age dependency ratio is expected to grow from 26.6 in 2015 to 48.2 in 2060 .

The life expectancy at birth of the Czech population has been strongly increasing over the past two decades. In 2014 , life expectancy (LE) at birth was 75.9 years for men and 82.1 for women. Healthy life years (HLY) at birth are estimated as 65.0 for females (79.2\% of total life expectancy) and 63.4 for males ( $83.6 \%$ of the total life expectancy). Life expectancy at age 65 is 19.9 years for females and 16.2 years for meals. Healthy life years constitute $46.7 \%$ (9.3 years) of this period for women and $52.5 \%$ ( 8.5 years) for men.

Box 1. Population ageing indicators.

Source: Based on Eurostat data, http://ec.europa.eu/eurostat/data/database; accessed: 14.10.2016.

Mortality for males aged $65+(5,469 / 100,000)$ is much higher than for females $(3,559 / 100,000)$ in the Czech Republic. The main causes of death are cardiovascular system diseases ( $48 \%$ of deaths in males and $53 \%$ in females), followed by cancers (26\% of deaths in males and $22 \%$ in females) and respiratory system diseases ( $7 \%$ of deaths in males and $11 \%$ in females).

Morbidity in the older population is high and increases with age. More than half of the population aged 65-74 reports long-standing illness or health problem $(49.9 \%$ of men $/ 52.6 \%$ of women). At the age of 85 the share raises to more than two thirds $(77.5 \%$ of men/79.2\% of women). The most common diseases in the older population are hypertension, arthritis, musculoskeletal disorders, chronic headaches and allergies. Diabetes (type 1 and type 2 ) is becoming a significant health problem, with a prevalence of $8 \%$ in the total population, which is above the OECD average of $6.9 \%$ in 2013 [7]. Seniors also often complain of suffering from sleep disorders, fatigue and chronic pain that negatively impacts quality of life [6].

In $2014,37 \%$ of men $39 \%$ of women aged $65-74$ reported some or severe limitations in regular activities due to health problems. The share of people with functional limitations increases with age. At the age of $75-84$, more than half ( $54.6 \%$ of men $/ 59.9 \%$ of women) and above the age of 85 two thirds of older people report long-standing limitations in everyday life $(72.7 \%$ of men/77.3\% of women).

The main risk factors of poor health in the adult population are high tobacco consumption, high consumption of alcohol and obesity. More than every fifth adult (22\%) reported smoking daily in 2013. The consumption of pure alcohol amounts to 11.5 litres per capita annually and is one of the highest in Europe. Obesity is becoming a significant health problem, increasing from $14 \%$ of obese adults in the population in 2000 to $21 \%$ in 2010 which results in a higher risk of diabetes and cardiovascular system diseases. According to the European Health Interview Survey, in the population aged 65 to $74,25 \%$ of males/36\% of females were obese (BMI greater than 30) in 2008. In the population above the age of 75 this share was also high, amounting to $11 \%$ for males $/ 23 \%$ for females.

Box 2. Health status of the older population.

Source: Based on European Health for All database (HFA-DB) WHO Regional Office for Europe, http://data.euro.who.int/hfadb/; accessed: 10.10.2016; Eurostat, EU-SILC data, http://ec.europa.eu/eurostat/data/database; accessed: 10.10.2015. 
ting, policy initiative and planning include the Ministry of Health of the Czech Republic, the National Institute of Public Health and the Ministry of Labour and Social Affairs. Education and research in public health is the responsibility of universities, with especially significant roles taken by the Charles University in Prague and Masaryk University in Brno. There are also several research institutes that provide comprehensive information on issues related to population ageing, long-term care, health status and quality of life in older age, i.e. the International Longevity Centre - The Czech Republic, oriented towards information, education and research on active and healthy ageing; ${ }^{5}$ the International Clinical Research Centre (ICRC) which is an independent research institution at St. Anne's Hospital in Brno performing clinical research on cardiology and neurology in the adult and older populations; and the Quality of Life Clinical Research Centre dedicated to promoting clinical research and education in the field of quality of life. An important medical profession organisation dealing with education and research on ageing and public health problems is the Czech Society for Gerontology and Geriatrics $^{6}$ established in the 1950s. There are also other associations actively involved in health promotion activities: the Czech Society for Oncology is very active in promoting the National Cancer Control Programme; the Czech Diabetes Society supports the National Diabetes Programme, etc.

\section{Health promotion in the health sector}

There are several health sector institutions involved in health promotion and prevention in the Czech Republic. Strategic planning of activities lies at the governmental level, supervised by the Ministry of Health and managed by the National Institute of Public Health. Within the National Institute of Public Health there are six departments: the Centre for Health and the Environment, the Centre for Health, Nutrition and Food, the Centre for Industrial Hygiene and Occupational Health, the Centre for Public Health Promotion, the Centre for Epidemiology and Microbiology and the Centre of Toxicology and Health Safety. Regional public health institutes and regional public health authorities are subordinate to the National Institute of Public Health.

Locally, recognition of health needs and implementation of prevention activities is supervised by district public health authorities and public health institutes. Activities are implemented at the local level and take place mainly within health care units. The health sector in the Czech Republic is hospital oriented, although a lot of attention has been given in recent years to strengthening the role of primary care in health promotion and prevention [7]. Primary care physicians are responsible for treatment of patients and disease prevention. According to a government resolution, every two years insurers, together with primary care physicians, are obliged to ensure access for all eligible adults to preventative measures, such as blood pressure screening, tests for blood sugar, cholesterol measures and urinalysis. An electrocar- diogram should be performed in every adult, 40 or older, every 4 years. The coverage and enactment of these measures, however, is not monitored.

There are several nationwide health promotion and prevention programmes targeted at the whole population, with older people being an important group of beneficiaries. Some of the health promotion programmes aimed at improvement of the population's health status were established in the 1990s and 2000s, such as the Healthy School and Healthy Cities Network, Healthy Family, Healthy Hospital, Healthy Workplace [6]. Health promotion activities are enacted within larger strategies addressing specific conditions or health determinants (i.e. the National Cancer Programme, the Food Safety and Nutrition Strategy) as well as under the authority of annual editions of the National Health Programme Health Promotion Projects, started in 1994. Within the state subvention of Health Promotion Projects, activities targeted at older population are also funded. In 2004 another grant programme entitled the Healthy Ageing Project was launched, however the age specific focus was abandoned after only three years [8]. Within the two projects, subsidies for health promotion and prevention activities have been granted to third sector organisations, research institutes, religious organisations or local governments (municipalities) for one year programmes. Activities for seniors supported with the state subvention have included information and education programmes, workshops, counselling, rental of health aids or appliances. Both grant projects were administered jointly by the Ministry of Health and the National Institute of Public Health.

\section{Prevention of cardiovascular system diseases}

Activities in prevention of cardiovascular diseases in the Czech Republic began in 1992 with the Programme for Reduction of Cardiovascular and Cerebrovascular Disease. The programme came into existence through the cooperation of three American and three Czech Institutes. It was led by the University of California at San Francisco while participants from the Czech side included the National Institute of Public Health (NIPH), the Institute for Clinical and Experimental Medicine (IKEM) and the Second Medical Clinic of the Third Medical Faculty of Charles University (SMC). The consortium managed to establish three clinics in Prague and Litomerice as well as a community intervention programme in Dubec ${ }^{7}$ addressing the risk factors for cardiovascular system diseases (a high fat diet, tobacco use etc.). In 1994 the pilot programme was a thorough information campaign and training of policy makers in health and prevention for the whole country. Until 1998 the programme was financed mainly from the US AID programme, with support from the Czech Ministry of Health and other foundations. In 1998 management and funding of the programme was fully overtaken by the Czech Ministry of Health. This programme was a cornerstone in cardiovascular disease prevention in the Czech Republic. 
Currently, activities concerning cardiovascular disease prevention are continued under the National Health Plan - Health Promotion Projects, supervised by the Ministry of Health. An example of such activities are projects granted in 2016 under the umbrella of the Kardiovize 2030 prevention scheme which aims at identifying and addressing the actual health risks of Brno's citizens. ${ }^{8}$ The first project phase concerns mapping risks related to cardiovascular system diseases and the second phase concerns targeting those risks with adequate health interventions. Two projects are funded in 2016 aimed at raising awareness of the negative health effects of smoking among students and raising awareness of lifestyle factors related to an increased risk of cardiovascular system diseases. The projects are managed by the International Clinical Research Centre.

\section{Prevention of cancer}

Prevention of cancer morbidity and mortality is undertaken within the National Cancer Control Programme. The aims of the programme include lowering the incidence and mortality rate of tumorous diseases and improving the quality of life of ill people with cancer, as well as rationalisation of diagnosis and treatment costs of cancerous diseases in the Czech Republic. The activities performed within the cancer control programme are very broad, starting with collecting information and monitoring cancer prevalence, organising cancer screening, organising a network of nationwide cancer treatment centres to assess the economic costs and HTA projects in cancer treatment. ${ }^{9}$ Three cancer screening programmes have been established over the last 15 years: breast cancer screening (2002), cervical cancer screening (2008) and colorectal cancer screening (2009). A network of comprehensive cancer centres was established in 2006. Comprehensive cancer centres are health care facilities which provide care to cancer patients and fulfil the crite- ria set by the Czech Society for Oncology. The network consists of highly specialised centres as well as district hospitals, specialised outpatient clinics and other health units. ${ }^{10}$ Since 1977 a national cancer registry has been in place (Czech National Cancer Registry).

\section{Prevention of diabetes}

Another nationwide public health programme, important from the population ageing point of view, is the National Diabetes Programme 2012-2022. The goals of the programme include prevention of type 2 diabetes with special attention given to obesity prevention, as the main risk factor for type 2 diabetes; systematic active screening of diabetes; improvement in the health outcomes of type 2 diabetes treatment; improvement in screening of late diabetes complications and its treatments; formation of a system for quality control and cooperation in treatment of diabetes in the health care system and cooperation with professional societies, the Ministry of Health and insurance companies. One of the main activities of the programme is stimulating the involvement of general practitioners in diabetes prevention and treatment as well as educating physicians and patients on issues related to diabetes prevention, treatment and the risks related to the potential complications of diabetes. The Programme was established in cooperation with the Czech Diabetes Society, the Diabetes Association of the Czech Republic and the Society of General Practitioners as well as being supported by other associations of medical professionals. There are several other programmes targeted at obesity prevention and activation of the population (i.e. the Food Safety and Nutrition Strategy 2014-2020, an action plan to promote physical activity in the Czech Republic from 2016-2020 [under preparation] and the National Strategy for Cycling Development 2013-2020) that support the activities of the National Diabetes Programme's other prevention programmes.

\footnotetext{
Pochod proti Alzheimerově chorobě (March against Alzheimer's disease)

On the International Day of Alzheimer's Disease (September $21^{\text {st }}$ ) an information and activation campaign took place in the major cities of the Czech Republic. ${ }^{11}$ In Praha, Plzeň, Jihlava, and Frýdek-Mistek a march against Alzheimer's disease was conducted, grouping numerous citizens, mostly of an advanced age. During the march, which wound through large parks, seniors were informed of the risks and symptoms related to Alzheimer's disease and dementia. The march was preceded with an information campaign in the media (TV spots, social media, youtube) and on the streets of larger towns (posters). Participants of the march received information leaflets and invitations to local events. An information campaign on the risks and symptoms of Alzheimer's diseases, combined with physical activity, has been conducted for the past several years (2014, 2015 and 2016).

Parky v pohybu (Parks in motion)

In 2016/2017 an action promoting outside sport activities among various population groups, with special attention given to seniors, is being undertaken. ${ }^{12}$ In towns of the Czech Republic, seniors are being invited to participate in organised trainings in parks. The trainings are undertaken regularly and supervised by a professional trainer. So far activities were performed in Praha, Olomouc, Přerov. The goal of the programme is to promote sport among older people and to prevent diseases for which inactivity is a risk factor, especially diabetes. Information on organised sport sessions is being spread locally on posters and via internet (social media, the project web-site). The project is financed by the National Health Plan of the Ministry of Health 2016.

60 a víc neznamená nic! (60 will not change a thing!)

This project took place in 2010/2011 in the city of Valašské Meziříčí and aimed at promoting exercise and sport activities, enabling joint meetings and sharing the experiences of people above the age of $60 .{ }^{13}$ Participants could choose from 16 sport activities, including swimming in an indoor pool, a gym work out, spinning class, an autumn walk or even Zumba dancing classes. Activities were undertaken regularly, once a week for the period of two years. Educationally, the project had ambitions of enabling an exchange of views and discussion between different generations. Participants received trainings in communication skills in various situations, health education, use of technology and the ability to recognise and resist manipulation by advertising and the media.
}

Box 3. Examples of health promotion and prevention activities for older people undertaken by the NIPH and local governments. Source: Own work. 


\section{Health Promotion for Older People}

While the above programmes target the total population and older people might be an important group of beneficiaries, there are also various programmes and projects in place specifically addressing the older population. These programmes aim to inform and educate regarding diseases specific to older age and their risk factors and to promote healthy behaviour. Several initiatives in this field have been undertaken in recent years by the National Institute of Public Health, Public Health Promotion Centre in cooperation with local authorities. Examples of these activities are shown below (Box 3).

Next to the central administration and local governments, non-governmental organisations, in many cases patient organisations (i.e. the Czech Alzheimer's society), are also very active in health promotion for seniors, the prevention of diseases, including the prevention of cognitive disorders, and activating seniors. Activities are often performed in day care centres run by local third sector organisations. Projects are undertaken in cooperation with local governments and are supported with governmental and international resources: the European Social Fund and the Norwegian Fund. Although the projects are organised based on time-fixed budgets related to funding availability, examples of organisations actively operating since the 1990s can be found. Innovative health promotion project have been piloted in older persons with dementia covering activities such as reminiscence therapy, dance therapy, gardening therapy [9]. Examples of such activities are presented below (Box 4).

\section{Barriers to prevention and health promotion activities}

Health promotion and prevention of diseases has not always been a policy priority in the Czech Republic. Only recently has the new concept of health promotion and the need for addressing different population groups with health promotion and prevention activities been conceptualised and operationalised [6] in national strategies and health plans, which although delayed are actively implemented. There are various barriers to planning and organising successful health promotion programmes. They include still insufficient research and recognition of needs in the health promotion field [6]. Andel [10] points to the insufficiency of longitudinal, population based studies that would allow the recognition of various aspects of ageing that could be a basis for formulating adequate health policy. On the other hand, there are cases when data is available (i.e. National Cancer Registry data), but it is not being sufficiently used [7]. There also problems with the implementation of health promotion and prevention activities and their sustainability. Whilst there are various programmes, they are not systematically coordinated and under the National Health Plan they are often granted for only a year or two, with no follow up. Another barrier is poor responsiveness from the (potential) beneficiaries. Cancer screenings undertaken in the National Cancer Prevention programme typically have low response rates with less than half of the potential beneficiaries of the programme participating [7].

\section{Health promotion in the social sector}

An important sector providing care to older people in the Czech Republic is that of social assistance, with social services and residential care granted to dependent people based on a dependency test. The provision of social services in the Czech Republic is defined by the Law on Social Services. ${ }^{16}$ This regulates the conditions for providing assistance and support to individuals in difficult social situations through social services and care allowances. The main objectives of the social services are: (1) reducing the social and health risks of users of the social services; (2) developing the abilities of those users, and (3) improving or at least maintaining the selfsufficiency of clients of social services. Social counselling, social care and social prevention represent the basic

\footnotetext{
Život 90 (Life 90)

This organisation, established in 1990, runs a community care centre in Praha and organises numerous programmes: free telephone assistance in case of crisis (so called Senior telephone), programmes aimed at stress relief, support for lonely people and depression prevention, emergency calls, nursing and personal care services, respite care services for older care providers and transportation, as well as a senior academy. ${ }^{14}$ The NGO organises activities for seniors, such as a dancing club, language courses and physical activity events. An example of the latter is a race for seniors Seniorská mile (Senior miles) organised in September 2016 in the Letna district (Praha).

EURAG Memory Training Centre

This is an organisation accredited by the Ministry of Labour and Social Affairs and sponsored by the Czech Society for Memory Training and Brain Jogging. ${ }^{15}$ Its goal is to enable seniors to apply techniques and strategies for remembering in their daily activities in order to support their independence. The Centre organises workshops and seminars for professionals and seniors every year to promote memory training methods. The first systematic workshops for memory trainers were organised in 1994. Now, the organisation continues with memory trainings for seniors and other interested parties, providing two sessions of workshops per year.

GEMA - Projekt Centra na Podporu Zdravi (GEMA - the Centre for Health Support)

This project, supported by senior organisations, the Czech Alzheimer's society and professionals in geriatrics and gerontology, aims at health promotion for seniors, development of gerontology, geriatrics and increasing the quality of care for the chronically ill in the Czech Republic. Activities within the project cover dance sessions, English classes and establishing an internet café for seniors as well as establishing a web-site (http://www.starnout-je-normalni.cz) aimed at popularisation of information related to the ageing process and providing information on current project activities. The project is supported with public and private funds and has been providing activities for the last 15 years.
}

Box 4. Examples of NGO activities in the field of health promotion for older people.

Source: Own work. 
types of social services. There is a very broad range of activities providing social services. These may include social counselling, educational and motivational activities, assistance with common activities of self-care and social welfare services etc. [11].

The state social support system is a non-contributory system which is financed from the state budget and administered by the assigned state bodies. Social service providers are: municipalities and regions, who look to form suitable conditions for the development of social services, in particular by researching people's real needs and the resources necessary to satisfy such needs, and who also set up organisations to provide social services; non-governmental non-profit organisations and individuals who provide a wide spectrum of services; and the Ministry of Labour and Social Affairs who is the incorporator of five specialised social care institutions. In the social area, self-governments (municipalities, regions), NGOs and other organisations have an opportunity to use funding from the European Social Fund. For some types of social services the municipalities and regions issue resolutions on services to be provided in administrative proceedings. This concerns, in particular, domiciliary care services and services associated with living in elderly homes. If an NGO is the service provider, the user enters into a contract with this provider. The resolution, or the contract, also includes a clause concerning the user's financial participation in the service provided.

The system of care for seniors who need a certain type of care is provided primarily by health and social services, which are not sufficiently interlaced. Out of the total number of 5,240 social services (National Action Plan 2014), 1,640 primarily target seniors, which accounts for $31 \%$ of the total volume of provided social services. In the abovementioned number of services focused mainly on seniors, 703 were residential care activities and 937 non-residential care activities. The Czech Republic offers basically two types of special housing solutions to older people who require more or less regular and extensive assistance from another person due to their age or chronic illness. These are domiciliary care service homes and homes for the elderly (residential homes). In addition to these special housing forms, there is one type of field-based social care services, i.e. domiciliary care services. Domiciliary care services mainly engage in tasks connected with practical assistance and help with self-maintenance, and are of crucial importance when considering promotion of healthy ageing. This kind of social care service is often complemented by medical home care [12].

Social personal care services are the most important services granted to older and dependent people based on the activities of daily living (ADL) dependency test and can be received either in home care, day-care or residential care. Most importantly, they are not directly linked to health promotion programmes or prevention activities but, while provided by medical or care professionals, they can be combined with advice and support regarding healthy lifestyle; undertaking and recommending activities suitable for seniors and dependent people. The scope of such activities has not, however, been assessed.

\section{Sources of health promotion financing}

Total expenditures on prevention in the Czech Republic are low, constituting about $3 \%$ of total health expenditures. However, according to the National Health Accounts, prevention related expenditures have been increasing over recent years more steeply than total health care expenditures (14\% between 2010 and 2014 compared to 3\% between 2010 and 2014). Expenditures on prevention programmes cover information and counselling, vaccination programmes, early detection of diseases and diagnosis including various types of screening, diagnostic tests and medical examinations as well as general population health monitoring (Table II).

The structure of expenditures on prevention is stable, with the largest share of expenditures $(65-66 \%)$ related to general population health monitoring, followed by expenditures on early detection programmes (15-16\%). Expenditures on vaccinations constitute about $14 \%$ of the total expenditures on prevention. The smallest share of expenditures $(5-7 \%)$ is related to information and counselling programmes, though it has been strongly increasing (by 30\%) between 2010 and 2014 (Figure 1).

\begin{tabular}{|l|c|c|c|c|c|c|}
\hline & $\mathbf{2 0 1 0}$ & $\mathbf{2 0 1 1}$ & $\mathbf{2 0 1 2}$ & $\mathbf{2 0 1 3}$ & $\mathbf{2 0 1 4}$ & $\begin{array}{c}\text { Change 2010-2014 } \\
\text { (2010=100) }\end{array}$ \\
\hline Preventive care & 9,990 & 10,364 & 10,595 & 10,765 & 11,433 & 114 \\
\hline Information and counselling & 487 & 497 & 626 & 629 & 637 & 131 \\
\hline Vaccinations & 1,389 & 1,432 & 1,484 & 1,458 & 1,576 & 113 \\
\hline Early detection and diagnosis & 1,573 & 1,554 & 1,586 & 1,644 & 1,659 & 105 \\
\hline Health monitoring & 6,541 & 6,881 & 6,900 & 7,034 & 7,561 & 116 \\
\hline Total health care expenditures & 339,852 & 342,753 & 347,605 & 348,860 & 350,411 & 103 \\
\hline
\end{tabular}

Table II. Expenditures on preventive care in the Czech Republic 2010-2014 (mln CZK).

Source: ČSÚ 2016, Zdravotnické účty ČR 2010-2014. 


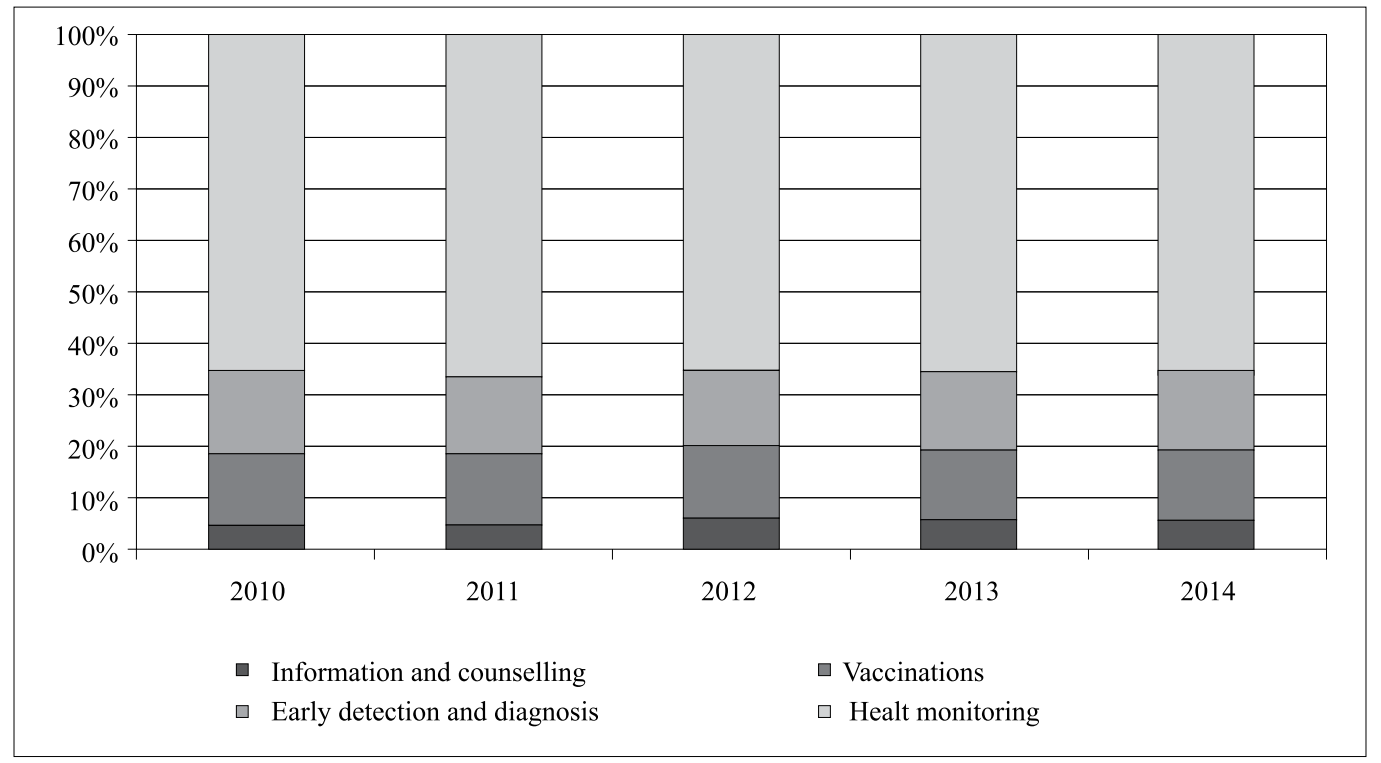

Figure 1. Structure of expenditures on preventive care 2010-2014.

Source: ČSÚ 2016, Zdravotnické účty ČR 2010-2014.

According to the National Health Accounts data preventive care in the Czech Republic is funded mainly from public sources $(78 \%) .81 \%$ of public funding comes from the social health insurance system and $17 \%$ from the state budget. Only a small share of preventive care (less than $2 \%$ ) is funded out of the local government budget. About $22 \%$ of preventive activities are funded from private (including corporate) sources (Table III).

The structure of financing depends on the type of prevention activity. Information and counselling programmes are financed predominantly from the health insurance system $(98.7 \%)$, with only $0.5 \%$ of sources from the state budget and $0.8 \%$ from local budgets. Vaccinations are financed mostly from the state budget
(96\%), while $2.1 \%$ of financial resources come from local budgets and $2 \%$ from the health insurance system. Early detection and diagnosis programmes are, on the other hand, financed mostly from the health insurance funds $(86.4 \%)$ while $7.4 \%$ of financial resources come from the state budget and $6.2 \%$ from local budgets. Only health monitoring is reported to be financed jointly from public and private sources. $65.9 \%$ of financial resources related to health monitoring come from the health insurance system and $34.1 \%$ from companies.

In the social sector expenditures related to prevention are marginal, constituting about $2-3 \%$ of total social sector long-term care expenditures [13, 14].

\begin{tabular}{|c|c|c|c|c|c|}
\hline & Preventive care & $\begin{array}{l}\text { Information and } \\
\text { counselling }\end{array}$ & Vaccinations & $\begin{array}{c}\text { Early detection and } \\
\text { diagnosis }\end{array}$ & Health monitoring \\
\hline Public sources & 8,202 & 637 & 1,325 & 1,659 & 4,581 \\
\hline Including: & & \multicolumn{4}{|c|}{ Structure of total expenditure (\%) } \\
\hline State budget & 1,398 & 0.5 & 96.0 & 7.4 & 0 \\
\hline Local budgets & 136 & 0.8 & 2.1 & 6.2 & 0 \\
\hline Health insurance & 6,668 & 98.7 & 2.0 & 86.4 & 65.9 \\
\hline Private sources & 2,374 & $\mathbf{0}$ & $\mathbf{0}$ & $\mathbf{0}$ & 2,374 \\
\hline Including: & & \multicolumn{4}{|c|}{ Structure of total expenditure (\%) } \\
\hline Private insurance & 0 & 0 & 0 & 0 & 0 \\
\hline Non-profit organisations & 0 & 0 & 0 & 0 & 0 \\
\hline Company sources & 2,374 & 0 & 0 & 0 & 34.1 \\
\hline Household & 0 & 0 & 0 & 0 & 0 \\
\hline
\end{tabular}

Table III. Funding of preventive care by source ( $m \ln C Z K)$.

Source: ČSÚ 2016, Zdravotnické účty ČR 2010-2014. 


\section{National ageing and health promotion policy}

There are two strategic governmental programmes that formulate policy towards healthy and active ageing in the Czech Republic: adopted in 2014 and based on the WHO Health 2020 policy, the Health 2020 - National Strategy for Health Protection and Promotion and Disease Prevention and, adopted in 2012 (further updated in 2014), the National Plan for Positive Ageing for the period 2013-2017. It should be underlined however that while these two documents are the most recent, health promotion, prevention of disease and ageing issues have been in the spotlight of national policy since the early 2000s. The National Strategy for Health Protection is a follow up to the Long-term Programme for Improving the Health of the Population of the Czech Republic Health for All in the 21st Century, endorsed by the government in 2002, and the Conceptual Framework for the Public Health Network and Primary Prevention in Public Health Protection, adopted in 2013. At the same time, the National Plan for Positive Ageing was preceded by the National Programme of Preparation for Ageing 20032007, which continued in its second edition, the National Programme of Preparation for Ageing 2007-2012. ${ }^{17}$ The two current main nationwide policy documents are linked, referring to each other's strategic objectives and planned activities.

The National Strategy for Health Protection and Promotion and Disease Prevention is a strategic document prepared by the Czech Ministry of Health in cooperation with the National Institute of Public Health and consulted with other ministries [15]. It constitutes a framework for the national level activities of different sectors with disease prevention and health promotion components and for establishing regional level disease prevention and health promotion programmes. The National Strategy is planned as an umbrella document tackling various activities that include elements of disease prevention, health protection and building up an integrated health care system. The overall goals of the programme focus on improving the health and well-being of the population by reducing mortality, reducing health inequalities and strengthening the role of public health in national and regional policy. Its objectives tackle health risks and the need for improvement of health services in disease prevention and health promotion on the one hand and are oriented on mechanisms for health investments on the other hand.

These objectives serve as a basis for formulating action plans in specific areas of health promotion and disease prevention. Actions are expected to be financed using funds provided within the European Structural and Investment fund for health care in the period of 20142020 as well as subsidies from the European Commission financial programme - The Third EU Health Programme 2014-2020 [15].

Healthy ageing is one of the 21 targets of the Health 2020 policy, under the priority of investing in health and disease prevention in the course of life. An aim of activities in the healthy ageing field is to prevent diseases which occur most commonly in older age, addressing the risk factors of these diseases, empowering older people, providing a safe and suitable environment and their health potential. Activities and programmes for older people could be also organised under the framework of other targets, such as: reducing communicable diseases, reducing non-communicable diseases, healthier living in communities, etc.

The second, inter-departmental strategic document with respect to ageing is the National Action Plan for Positive Ageing for the period of 2013-2017 prepared by the Ministry of Labour and Social Affairs [16]. The main goals of the programme refer to the fields of active ageing and human rights. They include strengthening national, regional and local policies in preparation for ageing, ensuring and protecting the human rights of older people, strengthening access to and use of lifelong learning by older people, supporting participation in the labour market by older workers and seniors, supporting volunteering by older people and intergenerational cooperation, improving the quality of life of older people with relevant infrastructure, access to housing and public facilities enabling participation in social life. Healthy ageing and care for older people are among the last, but not the least of the priorities listed in the NAP. Activities promoting a healthy lifestyle for older people and prevention of disease are perceived as prerequisites for a prolonged life, active ageing and high quality of later stages of life. Activities within the programme are financed from national and international subsidies, including European Commission funds, the Norwegian Fund and the Programme of Swiss - Czech Cooperation. Whilst strategies are elaborated, they face difficulties in implementation, including lack of adequate financing and organisation deficiencies.

A nation level organisation representing older people is the Government Council for Older Persons and Population Ageing, installed in 2006 in the Ministry of Labour and Social Affairs. The council consists of representatives of the government, NGOs, health insurance companies and other social partners. Its four working groups concentrate on the following priorities: (1) support of employment, lifelong learning and social security, (2) improvement of health and social services for seniors, (3) awareness raising and anti-discrimination, (4) housing and residential social services [6].

\section{Summary and conclusions}

The Czech population has entered an ageing phase with a sharp increase in the proportion of older people in the population in recent years. The health status of older people has been improving, which is reflected in rising life expectancy, but several risk factors related to an unhealthy diet and the risk of obesity, high alcohol consumption and smoking raise concerns in relation to the possibilities of morbidity compression in older age and the improvement of quality of life of older people.

Health promotion in health care policy is a field of growing importance, although expenditures on health 
promotion programmes are low in relation to total health care expenditures or GDP. Health promotion for older people has been getting more and more attention in the national public health and ageing policy in recent years. Healthy ageing measures have been explicitly included in the two crucial health promotion, prevention and ageing strategies: the National Strategy for Health Protection and Promotion and Disease Prevention and the National Action Plan for Positive Ageing for the period of 2013-2017. The existence of these two strategies enables implementation of various health promotion, disease prevention and activation programmes towards the older population, using national and international (mainly European) funds. Additionally, older people are beneficiaries of nationwide preventive programmes that target risks related to cardiovascular diseases, cancers and diabetes.

Governmental level institutions are responsible for drafting health promotion policy, especially the Ministry of Health and its direct subordinate, the National Institute of Public Health. An important role with respect to ageing is performed by the Ministry of Labour and Social Affairs, responsible for national plans for preparation for ageing and supervision of long-term care policy (social services). Whilst national programmes on health promotion and prevention, including those for older people, are in place, efforts are still needed to support regional and local governments as well as third sector organisations in implementation and management of activities aimed at health promotion for older people. As activities in health promotion are undertaken in health and social sector, it is of special importance for health promotion for older people to strengthen cross-sectoral cooperation between health services and social services, especially at the local level, as they share the same objective of improvement of the quality of life of older people.

Local, non-governmental organisations are crucial actors, upon whom successful implementation of promotion actions depends. They typically cooperate closely with the local administration and are often involved in provision of social services. At the same time they actively spread information on health risks and organise workshops and trainings for seniors that prevent social isolation, physical inactivity and cognitive dysfunctions, which are significant risk factors for the occurrence of many diseases common in older age. Their activities for seniors, often one of the links between health and social sector actions, should be further supported.

\section{Notes}

${ }^{1}$ Act No 258/2000 Call.

${ }^{2}$ Government resolution no. 1046/2002.

${ }^{3}$ Government resolution no. 810 .

${ }^{4}$ Government resolution no. 273/1992.

${ }^{5}$ http://www.ilc-alliance.org/index.php/members/details/ ilc-czech_republic.

${ }^{6} \mathrm{http}: / /$ www.cggs.cz/cz/Home/.

${ }^{7}$ http://www.ceche.org/programs/cze-cvd/cvdsum.htm.
8 http://www.fnusa-icrc.org/en/about-us/news/706-the-national-health-programme-grants-for-kardiovize-2030.html.

${ }^{9} \mathrm{http}: / /$ www.onconet.cz/index-en.php?pg=data-projects.

${ }^{10} \mathrm{http}: / /$ www.onconet.cz/index-en.php?pg=comprehensive-cancer-care.

${ }^{11} \mathrm{http} / / / \mathrm{www} . \mathrm{szu} . c z / 21$-zari-mezinarodni-den-alzheimerovy-choroby.

$12 \mathrm{http} / / /$ parkyvpohybu.wixsite.com/vyzva/vyzva-provsechny.

${ }^{13} \mathrm{http}: / / w w w . v a l a s s k e m e z i r i c i . c z / 60-a-v i c-n e z n a m e n a-$ nic/d-3312.

${ }^{14} \mathrm{http}: / /$ www.zivot90.cz.

${ }^{15} \mathrm{http} / / /$ www.trenovanipameti.cz/index.php?option=com content\&view $=$ article \&id $=67$ :eurag-mtc\&catid $=2$ :nezarazeno \&Itemid $=138 \&$ lang $=$ en.

${ }^{16}$ Act No. 108/2006 Coll.

${ }^{17} \mathrm{http}: / / w w w . m p s v . c z / e n / 4539$.

\section{References}

1. WHO, Health in Transition. Czech Republic, WHO Regional Office for Europe, Copenhagen 2015.

2. Klimentová E., Thelenová K., Welfare State and Social Work in the Czech Republic after the fall of Communism, "ERIS Web Journal" 2014; 1.

3. Włodarczyk C., Reformy zdrowotne. Uniwersalny kłopot. [Health reforms. Universal problem], Wydawnictwo Uniwersytetu Jagiellońskiego, Kraków 2003.

4. Kornai J., Eggleston K., Solidarność w procesie transformacji. Reforma stużby zdrowia w Europie wschodniej [Welfare, Choice and Solidarity in Transition. Reforming the Health Sector in Eastern Europe], Wydawnictwo Wyższej Szkoły Przedsiębiorczości i Zarządzania im. Leona Koźmińskiego, Warszawa 2002.

5. European Commission, Joint Report on Health Care and Long-Term Care Systems and Fiscal Sustainability, prepared by the Commission Services (Directorate-General for Economic and Financial Affairs), and the Economic Policy Committee (Ageing Working Group), volume 2 - Country documents, 2016, http://ec.europa.eu/economy_finance/ publications/eeip/pdf/ip037bycountry/joint-report_cz_ en.pdf; accessed: 10.09.2016.

6. Kř́žžová E., Brzyski P., Strumpel Ch., Billings J., Lang G., Health promotion for older people in the Czech Republic in a European Perspective, "Central European Journal of Public Health" 2010; 18 (2): 63-69.

7. OECD, OECD Reviews of Health Care Quality. Czech Republic Raising Standards. Executive Summary, Assessment and Recommendations, 2014, https://www.oecd.org/els/ health-systems/ReviewofHealthCareQualityCZECH_REPUBLIC_ExecutiveSummary.pdf; accessed: 07.09.2016

8. Krř́žová E., Vidovicová L., Gregorová E., Hábová M., Overview on health promotion for older people in the Czech Republic, Report of the Health pro Elderly Project, 2007.

9. Janečková H., Kř́žová E., Vzpomínejme společně: kreativní využití reminiscence $v$ rodinách pečujicich o člověka s demencí, "Sociální práce/Sociálna práce" 2012; 4: 51-55.

10. Andel R., Ageing in the Czech Republic, "The Gerontologist" 2014, doi:10.1093/geront/gnu047. 
11. Csemy L., Sovinova H., Managing risky drinking in social services setting. Field Test Strategy Czech Republic, 2014, http://www.bistairs.eu/material/WP6_material/Czech\%20 rep_ScS.pdf; accessed: May 2016.

12. Pfeiferova S., Lux M., Dvorak T., Havlikova J., Mikeszova M., Sunega P. (eds), HELPS: Housing and Home Care for the Elderly and Vulnerable People and Local Partnership Strategies in Central European Cities, Institute of Sociology, Academy of Sciences, Czech Republic 2013, http:// www.central2013.eu/fileadmin/user_upload/Downloads/ outputlib/HELPS_Main_Findings_Report.pdf; accessed: 15.05.2016

13. ČSÚ, Zdravotnické účty ČR 2010-2014, 2016, https://www. czso.cz/csu/czso/vysledky-zdravotnickych-uctu-cr-2015; accessed: 30.09.2016.
14. ÚZIS ČR, Zdravotnická ročenka České republiky 2013 [Czech Health Statistics Yearbook 2013], 2014, www.uzis. cz; accessed: 30.09.2016.

15. Ministry of Health of the Czech Republic, Health 2020 The National Strategy for Health Protection and Promotion and Disease Prevention, Prague 2014.

16. Ministry of Labour and Social Affairs, National Plan for Positive Ageing for the Period 2013-2017, Prague 2014, http://www.mpsv.cz/files/clanky/21727/NAP_EN_web.pdf; accessed 05.09.2016. 